https://doi.org/10.46344/JBINO.2021.v10i2b.16

\title{
A REVIEW ON TREATMENT STRATEGIES OF ARSHA (HAEMORRHOIDS/PILES)
}

\author{
Dr Santosh Babaraje Matkar, Dr Shivputra L.Balaraddi \& Dr Shridhar Waddar \\ PG SCHOLAR,SHALYA,SDMT'S AYURVEDIC MEDICAL COLLEGE,TERDAL \\ PROFESSOR,DEPARTMENT OF SHALYA TANTRA. \\ ASST.PROFESSOR, DEPARTMENT OF SHALYA TANTRA.
}

\begin{abstract}
Arsha (hemorrhoids) is engorgement of the hemorrhoidal venous plexus, characterized by bleeding per rectum, constipation, pain, prolapse and discharge. It is manifested due to improper diet, prolonged standing and faulty habits of defecation causing derangement of tridosha, mainly vata dosha. Vitiated dosha localizes in guda vali, pradhana dhamani and mansdhara kala and vitiates twak, mansa, meda and rakta, resulting in the annavaha sroto dushti. Modern management of arsha needs, mainly, a surgical approach, i.e. hemorrhoidectomy, wherein the result was found to be less satisfactory. In this article we are discussing regarding the various strategies of treatment of Arsha.
\end{abstract}

Keywords: Arsha, Dushti, defecation etc. 


\section{INTRODUCTION}

Ayurveda has immense potential to solve many challenging and unresolved problem of the medical world. Shalya Chikitsais one of the most important branches of ayurveda, which has its own originality with authenticity, contributing to the modern surgical technology to today, Sushruta Samhita is the only available text in surgical practice, and it has been opined that there are many diseases that are difficult to manage by conservative treatment alone. Among them arshais one such grave disease, for which it has been included in Ashtamahagada bysushruta, showing the gravity of this disease (3). The present westernized lifestyle is adding to the prevalent rate of this disease. The incidence of this disease is showing augmentation with advancing age. At least $50 \%$ of the people over the age 50 years have some degree of symptom related to arsha. In Sushruta Samhita, the whole treatment is covered under four categories of treatment i.e. Bheshaja chikitsa (palliative treatment), Ksharkarma (potential cauterization agent therapy), Agnikarma (direct cauterization agent therapy), Shastrakarma (operation). As far as modern modalities are concerned, the conservative treatment of piles consists of use of laxative and high residual diet. Arsha is being described by all the classics of Ayurveda. Acharya Sushruta even placed this disorder in the "Ashta Mahagada" 4 (Eight grave diseases). Arsha occurs in Guda region, which is undoubtedly a Marma, and it is well known for its chronicity and difficult management. This shows the gravity of the disease. Even WHO has declared 20th November of each year as "World Piles Day", which clearly indicates the infiltration of this disease all over the world and tremendous physical and mental sufferings of the mankind as result of this disease. Etymology and definition of Arsha (piles) Etymology: Arsha pertains to a

disease occurring in Guda and it is torturing to the patients. It may create obstruction of the anorectal passage. 5 Piles: - This word is derived from the latin word 'pila' which means a 'ball'. Thus a growth in the anus which similar in ball likes shape is designated as piles.

Sushruta Samhita is the only available text in surgical practice, and it has been opined that there are many diseases that are difficult to manage by conservative treatment alone. Among them, arsha (hemorrhoids) is one such grave disease, for which it has been included in ashta mahagada [1] by Sushruta, showing the gravity of this disease. The present westernized lifestyle is adding to the prevalent rate of this disease. The incidence of this disease is showing augmentation with advancing age. At least $50 \%$ of the people over the age of 50 years have some degree of symptoms related to hemorrhoids.

Hemorrhoids are dealt rationally under the concept of arsha. However, it includes some other fleshy masses like polyp, warts, etc. In Sushruta Samhita, the whole treatment is covered under four categories of treatment, i.e. Bheshaj Chikitsa (palliative treatment), Kshara Karma (potential cauterization agent therapy), Agnikarma (direct cauterization agent therapy) and Shastra Karma (operation by sharp instrument).

As far as the modern modalities are concerned, the conservative treatment of piles consists of use of laxative and high-residual diet. But, not more than $80 \%$ of the hemorrhoidal symptoms can usually be controlled by non-excision techniques. Other methods of treatments like sclerotherapy, rubber band ligation, 
infrared photocoagulation, laser therapy, Lord's dilatation,

hemorrhoidectomy, [4]

cryosurgery, artery ligation hemorrhoidal Doppler/ultrasonography and stapled hemorrhoidectomy, etc. are in practice. Despite a range of treatment modalities, the options are limited in concern with their effectiveness. There still exist controversies and lack of agreement on the treatment strategies.

Keeping in view authenticity, shalya chikitsa, i.e. parasurgery, has been selected. Under the heading of parasurgery, the kshara karma procedure, interpreted as "Potential Cauterization Application Therapy," is the specific field taken in the present research work. Under kshara karma, the kshara sutratreatment is found to be suitable and acceptable as compared with the prevalent methods in modern medical science.

Hence, in the present research work, the efficacy of the kshara sutra ligation (K.S.L.) method and hemorrhoidectomy procedure in arsha were studied clinically and results were presented statistically.

Kshar is a caustic chemical, alkaline in nature obtained from the ashes of medicinal plants. It is a milder procedure compared to Shastrakarma and Agnikarma. It is described as one among the Aanu Shastras or Upayantras. It is the superior most among the sharp and subsidiary instruments because of performing Chedana, Bhedana and Lekhana Karma along with Tridoshhara property. It is versatile, because even such places which are difficult in approach by ordinary measures can be treated by Kshar karma. Ksharkarma is more effective than the other modalities of treatment, because they can be administered both internally and externally. Kshar karma is useful as the substitutes of surgical instruments, because they can be used safely on the patients who are afraid of surgery. The Arsha which are soft, extensive, deeply situated, projectile are treated by Kshar. Pittaja and Raktaja varieties should be treated by Mrudu Kshar. Kshar Sutra Ligation It is a Parasurgical measure which excises the pile mass gradually by the virtue of mechanical action and chemical cauterization. Acharya Sushrutahas advocated Kshar Sutra in the management of Nadivrana and Bhagandara. But regarding the method of preparation of Kshar Sutra, Acharya Chakrapani in his treatise Chakradutta, gave a brief description for management of Arsha, using the latex of Snuhi and Haridra powder. 3.Agni Karma it is an important Para surgical method and is still used extensively in surgical practice in modified form by way of electric heat cautery and freezing. Direct treatment of any lesion by Agnikarma is regarded superior than other surgical and parasurgical measure because of its capacity to destroy the diseased tissues completely and its wide applicability even of lesions incurable by other measure. Agnikarma is indicated in rough, fixed, broad and hard types of masses and mainly in Vataj and Kaphaj Arsha. Those patients suffering from prolapsed and third degree piles can be treated with Agni. Agni karma is contraindicated in Raktaj and Pittaj type of Arsha. 4. Shastra karma Shastrakarma in indicated in pedunculated, big, and discharging Arshas. The preoperative measures should be well taken. The Chedana Karma of Arsha should be done with the help of sharp instruments like Mandalagra, Karapatra, Nakhashstra, 2021 April - May Special Edition / www.jbino.com | Innovative Association 
Mudrika, Utpalapatra and Ardhadhara in shape of semilunar incision. After Chedana Karma, if needed, Agnikarma should be immediately applied in case of any remnant or to arrest the active bleeding or secondary oozing of the blood vessels. The procedure of Kavalika placement followed by the Gophana Bandha should be performed. This whole procedure seems like conventional open haemorrhoidectomy or to say the ligation and excision procedure performed in recent times.

Arsha is a problem related to life style, age, occupation and dietary factors. It is a very terrible condition, patient is afraid of defecation because of pain with bleeding per rectum. Moreover, patient becomes very anxious after observing pan full of blood. Thus, Ayurveda definitely has immense potential to manage all stages of Arsha successfully without any complications.

\section{REFERENCES}

Kukreja Ajit Naniksingh Anorectal Surgery Made Easy. New Delhi; Jaypee Brothers Medical Publishers (P) Ltd. Replika Press Pvt.Ltd; 2013. p. 307.

Shastri Kaviraja Ambikadutta Sushruta samhita (Nidana Sthaana).Varanasi: Chaukhambha Sanskrit Sansthan; 2010. p.307. 8. B.D. Chaurasia human anatomy vol. - 2. New Delhi; CBS Publications; 2004.p.381-383.

Chaturvedi Gorakha Nath and Shastri Kasinath Charak samhita (Chikitsa sthana). Varanasi: Chaukhambha Bharati Academy; 2011 . p. 416.

Chaturvedi Gorakha Nath and Shastri Kasinath Charak samhita (Chikitsa sthana). Varanasi: Chaukhambha Bharati Academy; 2011 . p. 419.

Shastri Kaviraja Ambikadutta Sushruta samhita (Nidana Sthaana). Varanasi: Chaukhambha Sanskrit Sansthan; 2010. p.306.

Shastri Kaviraja Ambikadutta Sushruta samhita (Nidana Sthaana).Varanasi: Chaukhambha Sanskrit Sansthan; 2010. p.310.

S. DasA Concise text book of surgery Kolkata; Dr. Published by S. Das. 13, Old Mayor's Court;2014. p.1075-1076.

S. Das A Concise text book of surgery Kolkata; Dr. Published by S. Das. 13, Old Mayor's Court; 2014. p. 1077.

Shastri Kaviraja Ambikadutta Sushruta samhita (Nidana Sthaana). Varanasi: Chaukhambha Sanskrit Sansthan; 2010. p.306.

S. Das A Concise text book of surgery Kolkata; Dr. Published by S. Das. 13, Old Mayor's Court; 2014. p. 1075-1076.

Shastri Kaviraja Ambikadutta Sushruta samhita (Nidana Sthaana). Varanasi: Chaukhambha Sanskrit Sansthan; 2010. p.307-309.

S. Das A Concise text book of surgery Kolkata; Dr. Published by S. Das. 13, Old Mayor's Court; 2014. p. 1076-1077. 
S. Das A Concise text book of surgery Kolkata; Dr. Published by S. Das. 13, Old Mayor's Court; 2014. p. 1077. 20. S. Das A Concise text book of surgery Kolkata; Dr. Published by S. Das. 13, Old Mayor's Court; 2014. p. 1077-1078.

Shastri A. Chikitsa Sthana. 11 th ed. 03. Vol. 6. Varanasi: Published Chaukhamba Sanskrit Sansthan; 1953. Sushrutaacharya, Sushruta Samhita Dalhanacharya Kaviraj; p. 35

Goligher J, Duthie H, Nixon H. Surgery of the Anus, Rectum and Colon. 5th ed. A.I.T.B.S. Publishers and Distributors; 2002. pp. 131-34.
Shastri A. Chikitsa Sthan. $5 . \quad$ Vol. 6. Varanasi: Chaumbika Sanskrit Sansthan; 2001. Sushrutacharya, Sushruta Samhita, Ayurved Tatva Sandipika; p. 36.

Sharma SK, Sharma KR, Singh K. Kshara Sutra, Therapy in fistula-in-ano and other anorectal disorders. Rashtriya Ayurved Vidyapeeth (National Academy of Ayurveda): RAV Publication; 1994-95. pp. 48-52.

Sharma SK, Sharma KR, Singh K. Kshara Sutra Therapy in fistula-in-ano and other anorectal disorders. Rashtriya Ayurved Vidyapeeth (National Academy of Ayurveda): RAV-Publication; 1994-95. pp. $161-7$.
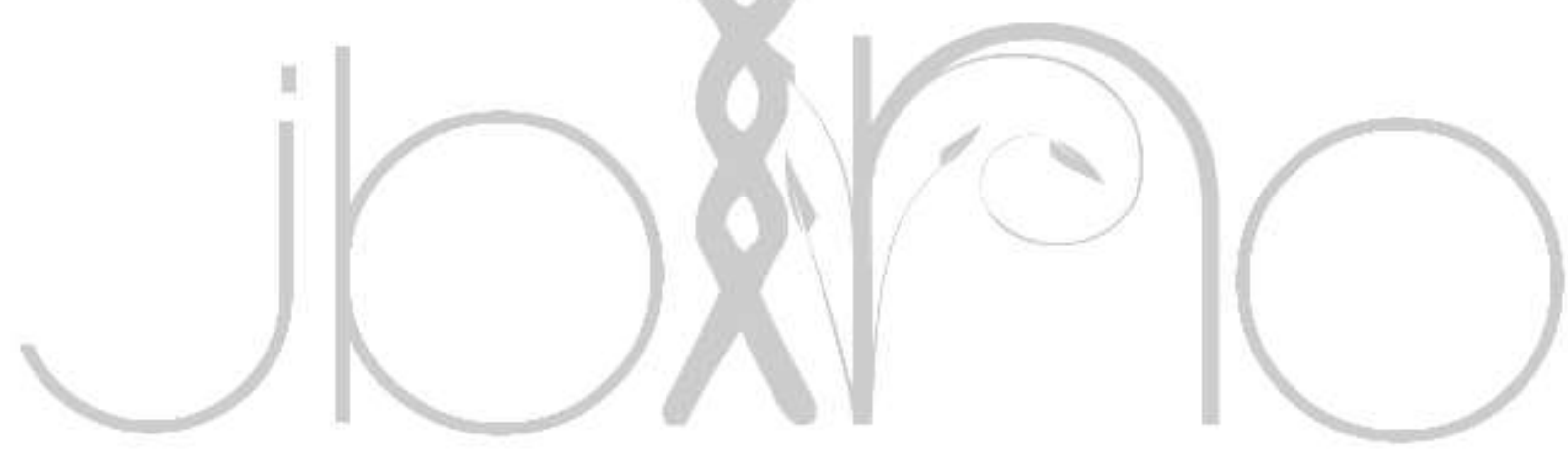